\title{
Pemanfaatan Aplikasi Edmodo dalam Evaluasi Pembelajaran Bahasa Arab di Masa Pandemi Covid-19
}

\author{
Hijriyatun ${ }^{1}$, Sutaman ${ }^{2}$, Laily Fitriani ${ }^{3}$ \\ 1UIN Maulana Malik Ibrahim Malang \\ 2UIN Maulana Malik Ibrahim Malang \\ 3UIN Maulana Malik Ibrahim Malang \\ Corresponding E-mail: hijriyatun@gmail.com
}

\begin{abstract}
Evaluation is carried out by the teacher to find out the the level of students capabilities to absorb a lesson convey by the teacher. By evaluating the teacher can take next step in order to that learning can be done optimally. The problem arises when the pandemic requires learning to be done from home and via the internet. Evaluation must be done online too. Writing this article aims to provide an overview of how evaluation activities were carried out during the Covid 19 pandemic, especially evaluating Arabic Learning by using the Edmodo application. The research location is on Mts Negeri 1 Pasuruan. This study used qualitative exploratory research with descriptive research methods. The main data sources in this study were students of Mts Negeri 1 Pasuruan with a total of 120 respondents. Evaluation using edmodo is one solution for Arabic Teachers in evaluating Arabic learning using digital technology, especially during the COVID-1 pandemic. The results of this study explain that evaluation using Edmodo makes it easier for teachers to monitor the learning outcomes received by students in learning Arabic.
\end{abstract}

Keywords: Evaluation of Learning Arabic, E Learning, Edmodo, Covid Pandemic 19

\begin{abstract}
Abstrak
Evaluasi dilakukan guru untuk mengetahui sejauh mana tingkat kemampuan peserta didik dalam menyerap suatu pelajaran yang disampaikan oleh guru, dengan melakukan evaluasi guru bisa mengambil langkah selanjutnya agar pembelajaran bisa dilakukan dengan maksimal. masalah muncul ketika diera pandemic covid 19 yang mengharuskan belajar dilakukan dari rumah dan melalui internet. Evaluasi pun harus dilakukan secara online. Penulisan artikel ini bertujuan untuk memberikan gambaran bagaimana kegiatan evaluasi dilakukan pada masa pandemic covid 19, khususnya evaluasi pembelajaran bahasa arab menggunakan aplikasi Edmodo. Lokasi penelitian adalah Mts Negeri 1 Pasuruan. Penelitian ini menggunakan penelitian kualitatif yang bersifat eksploratif dengan metode penelitian deskriptif, Sumber data utama dalam penelitian ialah siswa Mts Negeri 1 Pasuruan dengan jumlah sebanyak 120 orang responden. Evaluasi menggunakan edmodo merupakan salah satu solusi untuk guru bahasa arab dalam melakukan evaluasi pembelajaran bahasa Arab dengan menggunakan teknologi digital, terlebih diera pandemic covid 19. Hasil penelitian ini menjelaskan bahwa evaluasi dengan memanfaatkan edmodo membuat guru lebih mudah memantau hasil pembelajaran yang diterima oleh peserta didik dalam belajar bahasa arab.
\end{abstract}

Kata kunci : Evaluasi Pembelajaran Bahasa Arab, E Learning, Edmodo, Pandemi Covid 19 


\section{PENDAHULUAN}

Kemampuan siswa dalam menyerap ilmu yang diberikan oleh guru akan terlihat pada saat evaluasi dilakukan. Tanpa adanya evaluasi pada suatu kegiatan pembelajaran maka akan sangat sulit mengetahui tingkat kemampuan peserta didik dan juga akan sulit mengetahui apakah tujuan pembelajaran telah tercapai atau bahkan sama sekali tidak ada kemajuan. Bagi peserta didik, adanya evaluasi yang dilakukan oleh guru, siswa dapat mengetahui dan menentukan apakah hasil belajarnya baik atau buruk, memuaskan atau tidak dan tentu akan memberi motivasi pada siswa untuk meningkatkan kualitas belajar mereka. Bagi guru, evaluasi merupakan alat yang bisa digunakan untuk menentukan dan mengetahui manakah siswa yang sudah mencapai target pembelajaran dan memenuhi persyaratan untuk melanjutkan pada tingkat selanjutnya dan siswa yang belum bisa memenuhi target pembelajaran untuk bisa dilakukan remedial. Dengan evaluasi juga guru bisa mengetahui apakah materi yang diajarkan sudah tersampaikan dengan baik atau belum dan apakah metode dalam memberikan pembelajaran sudah benar atau belum tepat. Oleh karena itu evaluasi adalah suatu hal yang mutlak dilakukan oleh seorang guru dalam sebuah proses pembelajaran.

Adanya wabah covid 19 yang melanda dunia dan tidak terkecuali Indonesia, mengakibatkan pemerintah melalui Kementerian Pendidikan dan Kebudayaan mengambil keputusan untuk melakukan pembelajaran dengan system daring atau dengan menggunakan system Pembelajaran Jarak Jauh, keputusan ini diambil demi kesehatan dan keselamatan guru dan siswa dan agar memutus penyebaran virus covid 19 agar tidak semakin meluas dan memakan banyak korban jiwa. Adapun kenaikan kelas dilaksanakan dengan ketentuan (a) Ujian Akhir Semester untuk kenaikan kelas dalam bentuk tes yang mengumpulkan siswa tidak boleh dilakukan, kecuali yang telah dilaksanakan sebelum terbitnya edaran ini; (b) UAS untuk kenaikan kelas dapat dilakukan dalam bentuk portofolio nilai rapor dan prestasi yang diperoleh sebelumnya, penugasan, tes daring, dan/atau bentuk asesmen jarak jauh lainnya. Menurut mas Menteri bapak Nadiem makarim, proses kenaikan kelas bisa dilakukan dengan ketentuan : (1) Tidak melakukan penilaian dengan model tes yang mendatangkan siswa di sekolah kecuali tes tersebut dilakukan sebelum terbitnya Surat Edaran dan kementrian pendidikan dan Kebudayaan, (2) 
Untuk Penilaian Akhir semester sebagai syarat kenaikan kelas bisa dilakukan dalam bentuk portofolio nilai raport dan prestasi yang diperoleh oleh siswa, penugasan yang diberikan oleh guru, tes yang dilakukan secara online dan model penilaian jarak jauh yang lain. Mas menteri juga mengatakan "Baik Ujian Sekolah maupun Ujian Akhir Semester dirancang untuk mendorong aktivitas belajar yang bermakna, dan tidak perlu mengukur ketuntasan capaian kurikulum secara menyeluruh,"

Sedangkan mengenai belajar dari rumah. Menteri Pendidikan dan Kebudayaan memberi penekanan bahwa kegiatan belajar online (daring) dilakukan guna memberi pengalaman belajar yang bermakna untuk peserta didik, peserta didik tidak dituntut untuk secara tuntas menyelesaikan seluruh capaian kurikulum, untuk kenaikan kelas maupun kelulusan. Beliau berpesan "Kami ingin menganjurkan bagi daerah yang sudah melakukan belajar dari rumah agar dipastikan gurunya juga mengajar dari rumah untuk menjaga keamanan guru, itu sangat penting". Belajar secara daring/ jarak jauh difokuskan pada meningkatnya pengetahuan siswa tentang virus korona serta wabah Covid- 19. Mengenai kegiatan dan tugas belajar peserta didik bisa bermacam- macam antar siswa, disesuaiakan dengan kecenderungan minat masing masing peserta didik, begitupun perihal kesenjangan akses/ sarana belajar di rumah. Fakta ataupun produk kegiatan belajar diberi umpan balik yang bertabiat kualitatif serta bermanfaat dari guru, tanpa diwajibkan berikan skor/ nilai kuantitatif. "Walaupun banyak sekolah menerapkan belajar dari rumah, bukan berarti gurunya hanya memberikan pekerjaan saja kepada muridnya. Tetapi juga ikut berinteraksi dan berkomunikasi membantu muridnya dalam mengerjakan tugasnya. Mohon walaupun bekerja dari rumah, mohon siswa-siswa kita juga dibimbing," papar Mendikbud. (Mendikbud Terbitkan SE Tentang Pelaksanaan Pendidikan Dalam Masa Darurat Covid-19, 2020)

Berdasarkan data Worldometer, Minggu 14 Maret 2021, jumlah kasus positif Covid-19 yang terkonfirmasi di seluruh dunia bahkan telah mencapai 120.028.479 kasus. Kasus tersebut diantaranya kasus kematian sebanyak 2.658.679, kasus sembuh 96.529.551 dan sisanya dalam proses pemulihan, tercatat dari 221 negara di dunia.(Media, 2021), sedang didalam negeri yaitu Indonesia tercatat Jumlah orang yang terkonfirmasi covid 19 pada jumat 12 Maret 
2021 berdasar pada data situs Covid19.go.id, ditemukan penambahan kasus positif Covid 19 sebanyak 6.412 kasus, sehingga total jumlah kasus terkonfirmasi positif covid 19 di Indonesia telah mencapai 1.410.134 pasien positif covid 19.(UPDATE Corona Indonesia 12 Maret 2021, t.t.).

Menurut kajian yang dilakukan Syahruddin Damanik, dkk memberi kesimpulan bahwa, dengan adanya perubahan pada sistem pembelajaran yang menggunakan sistem tatap muka kemudian berubah menjadi system pembelajaran secara daring menimbulkan banyak sekali kesulitan-kesulitan yang dihadapi oleh guru, wali siswa dan peserta didik. Diantara kesulitan tersebut adalah: (1) Guru mengalami kesulitan ketika akan memilih bentuk dari evaluasi pembelajaran. (2) Guru juga mengalami kesulitan dalam pemetaan indikator capaian hasil belajar, (3) Aspek aspek penilaian kejujuran sangat sulit untuk diterapkan.(Damanik dkk., 2020, hlm. 155)

Selanjutnya penelitian yang dilakukan oleh Muh, Fitra dan Ruslan menyimpulkan bahwa, kegiatan evaluasi hasil belajar yang dilakukan selama pandemic covid 19 yang dilakukan oleh sekolah tidak berjalan maksimal dan kurang efektif, apalagi evaluasi hasil belajar pada aspek kognitif, aspek afektif dan aspek psikomotorik. Guru hanya bisa memanfaatkan aplikasi WhatsApp sebagai media utama dalam proses penilaian dan evaluasi walaupun ada juga yang memakai aplikasi Zoom Meeting. Hal tersebut membuktikan bahwasanya guru hanya mengambil kesimpulan dari hasil tugas yang diberikan oleh guru tanpa mengetahui proses peserta didik mengerjakan tugas tersebut. Kendala lain yang dialami oleh guru dalam melaksanakan evaluasi hasil belajar siswa adalah: guru mengalami kebingungan dalam memilih instrumen mana yang akan dipakai dalam evaluasi pembelajaran, kemampuan guru, orangtua dan siswa yang masih rendah dalam penggunaan teknologi, lemahnya partisipasi siswa dalam pelaksanaan evaluasi pembelajaran, keterbatasan kepemilikan handphone, jaringan internet yang lemah serta terbatasnya kuota internet siswa yang hanya mengandalkan bantuat kuota dari pemerintah.(Moh. Fitrah \& Ruslan, 2021, hlm. 178)

Sedangkan penelitian yang dilakukan oleh Syindi dan febri menyimpulkan Dalam aktivitas pendidikan di masa darurat Covid- 19, evaluasi pembelajaran dapat merujuk pada regulasi/ juknis evaluasi hasil belajar dari Kemendikbud ataupun Kemenag dengan penyesuaian masa darurat Covid 19. Evaluasi bisa 
dicoba dalam wujud pemberian tugas, proyek, tulis ataupun wujud yang lain yang diperoleh lewat daring ataupun wujud yang lain yang diperbolehkan untuk dilakukan secara jarak jauh serta senantiasa mencermati protokol kesehatan. Evaluasi bisa berupa evaluasi pekanan, evaluasi tengah semester, serta evaluasi akhir semester. Pemberian tugas serta evaluasi yang diberikan kepada partisipan didik bisa bermacam- macam antar siswa, menyesuaikan keadaan tiap- tiap perserta didik, dengan memperhatikan kemampuan dan kesenjangan akses serta ketersediaan sarana belajar di rumah. Pemberian tugas hendaknya sesuai porsi dan tidak berlebihan, supaya proteksi kesehatan, keamanan serta motivasi partisipan didik sepanjang masa darurat senantiasa terpelihara. Evaluasi dirancang agar menimbulkan kegiatan belajar yang bermakna serta tidak harus memaksa mengukur ketuntasan capaian pendidikan pada kurikulum secara merata. Evaluasi hasil belajar mencakup aspek perilaku, pengetahuan serta keterampilan.

Dalam pembelajaran bahasa Arab aspek pengetahuan bisa dinilai lewat uji lisan serta tulisan baik dicoba online ataupun offline. Aspek perilaku bisa dinilai dari reaksi serta usaha yang dicoba oleh partisipan didik sepanjang melaksanakan kegiatan pembelajaran, baik disaat pembimbingan, pengerjaan tugas, sampai mengantarkan hasil pengerjaan tugas. Aspek keahlian bisa dinilai lewat hasil karya yang dibuat oleh partisipan didik semacam membuat kartu tentang mufradat yang terdapat di dalam rumah pada modul البيت Pendidik melaksanakan evaluasi baik dengan metode skala capaian pertumbuhan, ataupun hasil karya setelah itu dianalisis untuk mengetahui ketercapaian kompetensi dasar yang timbul lewat scoring.(Tolinggi \& Ramadani S, 2020)

Penulisan artikel ini bertujuan untuk memberikan gambaran bagaimana kegiatan evaluasi dilakukan pada masa pandemic covid 19, khususnya evaluasi pembelajaran bahasa arab. Evaluasi pembelajaran bahasa Arab yang dimaksud adalah evaluasi dengan menggunakan E learning yang dalam hal ini menggunakan aplikasi Edmodo di MTs Negeri 1 Pasuruan. Diharapkan penulisan artikel ini menjadi salah satu solusi untuk guru bahasa arab dalam melakukan evaluasi pembelajaran bahasa Arab dengan menggunakan teknologi digital pada saat ini, terlebih diera pandemic covid 19 yang belum juga ditemukan obat dan solusi pencegahan penularannya selain melakukan pembelajaran dari jarak jauh. 


\section{KAJIAN TEORI}

E-learning terdiri atas dua kata yaitu "e" yang merupakan akronim dari electronica dan berarti elektronik serta "learning" yang mempunyai arti pembelajaran. Padanan kata e-learning dalam bahasa Indonesia adalah pembelajaran elektronik istilah e learning mempunyai definisi yang luas sehingga Banyak pakar yang mendefinisikan nya dari berbagai sudut pandang yang berbeda Jadi sebenarnya e-learning adalah proses dan aktivitas implementasi pembelajaran berbasis web pembelajaran berbasis komputer kelas virtual dan atau kelas digital materi pembelajaran pada kegiatan e-learning disampaikan dengan media intranet, internet, video-video penyiaran dengan satelit, TV interaktif dan CD room. Pada dasarnya e-learning adalah sebuah sistem atau perangkat pengajaran berbasis teknologi (computer atau smartphone) yang membuat peserta didik belajar dari mana saja dan kapan saja tanpa terhalang ruang dan waktu pada implementasinya e-learning yang ada saat ini sangat beragam namun semuanya didasarkan pada satu konsep bahwa e-learning adalah sebuah upaya distribusi materi dan bahan pembelajaran dengan media elektronik dan internet sehingga peserta didik bisa mengakses setiap saat dari berbagai penjuru dunia.

Pengembangan e- learning perlu dirancang sedemikian rupa sehingga bisa menyesuaikan dengan tujuan pendidikan yang diharapkan, dan yang paling utama dalam pemakaian internet, Haughey menerangkan terdapat paling tidak 3 model pengembangan sistem pendidikan berbasis internet ialah website course, website centric cours serta website Enchanced course. Website course dimaksud selaku pemakaian internet buat keperluan dunia pembelajaran yang prakteknya partisipan didik serta pengajar terpisah seluruhnya serta tidak diperlukan terdapatnya tatap muka, seluruh bahan ajar, penugasan, dialog, latihan, konsultasi, tes, serta aktivitas pendidikan yang lain seluruhnya diberikan melalui media internet dengan makna lain model ini menggunakan sistem pendidikan jarak jauh.

Model yang kedua website centric course merupakan pemanfaatan internet yang mencampurkan antara konsep belajar jarak jauh serta terdapatnya tatap muka( konvensional) sebagian modul diajarkan lewat internet serta sebagian yang lain lewat tatap muka dengan model ini pengajar bisa membagikan arahan serta petunjuk pada partisipan didik buat menekuni modul serta bahan ajar lewat 
website yang sudah terbuat. Partisipan didik diberi arahan pula agar mencari sumber belajar lain dari web yang relevan setelah itu ketika belajar tatap muka partisipan didik dan juga pengajar lebih fokus serta banyak dialog tentang penemuan materi ajar yang sudah di informasikan lewat internet model elearning yang kedua ini kerap diketahui dengan sebutan blended learning atau belajar campuran.

Ada pula model yang ketiga yang diketahui dengan sebutan website course ialah wujud pemanfaatan internet yang digunakan mendukung kenaikan mutu pendidikan yang dilaksanakan dalam kelas. Penggunaan internet merupakan alat pengayaan dan menjadi media komunikasi antara partisipan didik dengan pengajar, sesama partisipan didik dengan anggota kelompok ataupun partisipan didik dengan narasumber lain. Pengajar dalam model ini senantiasa dituntut memahami metode serta metode mencari data di internet membimbing partisipan didik mencari serta menciptakan web yang relevan dengan sumber serta bahan belajar, menyajikan bahan serta modul lewat website yang menarik atensi, melayani tutorial konseling serta komunikasi lewat internet serta kecakapan lain yang diperlukan. Di antara model yang di informasikan Hughey di atas model yang baik pasti tergantung pada suasana serta keadaan ketika model tersebut digunakan tetapi yang berarti serta perlu untuk dicermati merupakan seluruh aspek pembelajaran di dalamnya bukan cuma aspek kognitif namun pula aspek psikomotor dan aspek afektif secara terpadu di samping itu aspek lain semacam aspek Psikologi serta sosial budaya jadi bahan pertimbangan yang butuh dicermati dalam penerapan e- learning supaya tujuan pendidikan betul- betul tercapai. (Fauzi \& Anindiati, 2020, hlm. 33)

Pemanfaatn e-Learning berbeda beda dalam tiap implementasinya. Bergantung pada aspek yang berpengaruh pada kepentingan proses belajar antara lain ciri materi ajar dan kemampuan partisipan didik, tujuan belajar, fasilitas serta prasarana yang dipunyai, sampai kebijakan yang diterapkan dalam penerapan pendidikan. Peruntukan E-learning ialah : selaku supplement atau tambahan pada aktivitas belajar apabila digunakan untuk pendidikan tatap muka, sebagai supplement pada dimensi cakupan jenis dan materi apabila digunakan sebagai pengayaan terhadap materi yang harus dikuasai oleh peserta didik, sebagai supplement pembelajaran dapat digunakan untuk mengukur tingkat kemandirian 
belajar peserta didik. Kedua, sebagai complement (pelengkap) pada dimensi bentuk kegiatan belajar apabila digunakan untuk melengkapi pembelajaran tatap muka, sebagai complement pada dimensi cakupan dan jenis materi apabila digunakan untuk melengkapi materi pembelajaran yang diterima peserta didik. Ketiga, sebagai replacement (pengganti) pada dimensi bentuk kegiatan belajar apabila digunakan sebagai pengganti pembelajaran tatap muka, bentuk pembelajaran ini disebut sebagai fully e learning yang sudah digunakan diberbagai instansi atau lembaga pendidikan di Indonesia terlebih lagi disaat mewabahnya virus Covid 19, e learning bisa menjadi ganti kegiatan belajar tatap muka dimulai dari proses belajar sampai kepada proses evaluasinya dan pada aspek jangkauan dan jenis materinya model pembelajaran menggunakan e-learning memberikan bermacam macam pilihan jenis materi yang memungkinkan diakses oleh siswa.(Wahyuningsih \& Makmur, 2017, hlm. 12)

Edmodo merupakan satu diantara sekian banyak e learning yang bisa dimanfaatkan guru dalam pembelajaran bahasa Arab untuk melakukan evaluasi di era pandemic Covid-19. Edmodo ialah sebuah platform pembelajaran social untuk guru, dosen, siswa atau mahasiswa maupun untuk orangtua/ wali siswa, Nic Borg dan Jeff O'Hara adalah dua orang yang mengembangkan aplikasi ini sejak tahun 2007-2008. Aplikasi Edmodo berbasis social media dan menyajikan kiat yang aman serta memudahkan siswa agar bisa terkoneksi dan bekerjasama, saling membagikan konten dan hasil belajar, hasil evaluasi dan informasi dari pihak sekolah. Edmodo bisa membantu guru dan dosen merancang sebuah kelas virtual yang didasarkan pada pembagian kelas sebenarnya disekolah, yang mana dalam kelas online itu memuat pemberian tugas, kuis dan penilaian ketika pembelajaran berakhir. Edmodo termasuk kedalam Learning Management System (LMS) yang dipergunakan untuk proses belajar.(Fauzi \& Anindiati, 2020, hlm. 75)

Basori berpendapat Edmodo ialah aplikasi yang menyamai facebook tetapi dengan tingkat pemeelajaran yang besar, sehingga menarik untuk digunakan oleh guru maupun siswa.(Basori, 2013) Sedangkan Suriadhi mendefinisikan Edmodo selaku platform media sosial yang acapkali diasumsikan sebagai semacam facebook buat sekolah serta mempunyai fungsi lebih banyak lagi menyesuaikan dengan kebutuhan guru dan kepentingan siswa,(Suriadhi dkk., 2014) dengan kata lain Edmodo hamper sama dengan facebook akan tetapi Edmodo cenderung lebih 
bernilai edukasi serta sangat sering dipergunakan dalam aktifitas pembelajaran. Edmodo bisa dimanfaatkan menjadi media belajar pada seluruh mata pelajaran, seperti halnya mata pelajaran Bahasa Arab. Fitur fitur yang terdapat dalam aplikasi edmodo diantaranya : Group, Note, Alert, Assigment, Quiz, Polling, Library, Progress, Edmodo Planner. Diantara kelebihan yang dimiliki Edmodo yaitu : 1) Proses belajar mengajar tidak tergantung pada waktu ataupun tempat pembelajaran berlangsung, 2) Meringankan tugas guru ketika melakukan evaluasi pembelajaran, 3) orang tua ataupun wali peserta didik bisa memantau kegiatan belajar serta prestasi dari anak anaknya, 4) Menjadikan kelas lebih hidup sebab membolehkan interaksi guru dengan siswa ataupun siswa dengan siswa dalam perihal pelajaran ataupun tugas, 5) memberi fasilitas kerja secara berkelompok yang multidisiplin, 6) membuat suasana lingkungan virtual kolaboratif yang menciptakan pembelajaran berbasis proses. Sebagai aplikasi edmodo juga memiliki kekurangan yaitu : : 1) Bahasa program yang digunakan masih meggunakan Bahasa Inggris akibatnya terkadang mempesulit guru dan peserta didik, 2) Sintaks online secara langsung pada Edmodo belum tersedia.

Dalam pembelajaran bahasa Arab, terdapat 4 maharah (keterampilan) berbahasa yang dipelajari oleh siswa yaitu maharah istima', maharah kalam, maharah qiroah, dan maharah kitabah. Evaluasi pada maharah istima' dilakukan dengan cara mengukur kemampuan siswa dalam hal mengidentifikasi huruf, mencari perbedaan pada bunyi huruf huruf yang mempunyai kemiripan, memahami arti mufradat dan frasa, memahami kalimat, memahami wacana, memberikan respon atau tanggapan terhadap isi wacana yang disimak.(Ainin dkk., 2006, hlm. 135). Evaluasi pada maharah kalam dengan cara mengukur kemampuan siswa dalam mengucapkan kosa kata baru dengan pelafalan yang baik dan benar, mengucapkan materi percakapan dengan pelafalan dan intonasi yang baik dan benar, mempraktikan materi percakapan dengan berpasangan, melakukan tanya jawab dengan kosakata dan pola kalimat yang diajarkan, melakukan tanya jawab mengenai bahan Qira'ah berbahasa Arab yang telah diprogramkan.(Matsna \& Mahyudin, 2012, hlm. 153) Evaluasi pada maharah qiroah dilakukan dengan cara mengukur kemampuan siswa dalam hal lancar dalam membaca, cermat dan tepat, mengartikan kosakata dalam konteks kalimat tertentu, menentukan fakta tersurat dalam teks, menentukan arti tersirat dalam 
teks, menentukan ide pokok dalam paragraf, menentukan ide penunjang dalam paragraph, menghubungkan ide-ide yang terdapat dalam bacaan, menyimpulkan ide pokok bacaan, menangkap pesan sebuah bacaan dengan cepat, Mengomentari dan mengkritisi bacaan.(Ainin dkk., 2006, hlm. 172) Evaluasi maharah kitabah dilakukan dengan cara mengukur kemampuan siswa dalam hal mengurutkan kata menjadi kalimat, menyusun kalimat berdasarkan gambar, menyusun kalimat berdasarkan kosakata, mengurutkan kalimat menjadi paragraph, mendeskripsikan objek atau gambar tunggal berdasarkan pertanyaan, mendeskripsikan objek atau gambar tunggal, mendeskripsikan gambar berseri, menyusun paragraph berdasarkan pertanyaan.(Ainin dkk., 2006, hlm. 179)

\section{METODE PENELITIAN}

Penelitian ini menggunakan penelitian kualitatif yang bersifat eksploratif dengan metode penelitian deskriptif. Secara umum, penelitian kualitatif ialah mengedepankan narasi ilmiah sebagai bentuk eksplorasi hasil penelitian.(Muh Fitrah, 2018) Penelitian deskriptif adalah suatu metode penelitian yang ditujukan untuk memberi gambaran kejadian kejadian yang ada yang tengah terjadi pada saat ini atau saat yang lalu, tidak ada manipulasi atau pengubahan pada variabelvariabel bebas dalam penelitian ini, akan tetapi memberi gambaran suatu keadaan apa adanya pendeskripsian keadaan ini bisa secara individu atau mempergunakan angka-angka.(Sukmadinata, 2012) Sumber data utama dalam penelitian ialah siswa Mts Negeri 1 Pasuruan dengan jumlah sebanyak 120 orang responden. Data dikumpulkan dengan menggunakan observasi, wawancara dan dokumentasi. Sehingga instrumen utama dalam penelitian ialah peneliti, dan dibantu dengan lembar wawancara menggunakan google form dan alat rekam seperti handphone dan kamera. Analisis data dengan langkah pengumpulan data, reduksi data, penyajian data, dan penarikan kesimpulan. Analisis data adalah proses mencari dan menyusun secara sistematis data yang diperoleh dari hasil wawancara, catatan lapangan, dan dokumentasi, dengan cara mengorganisakikan data kedalam kategori, menjabarkan kedalam unit unit, melakukan sintesa, menyusun kedalam pola, memilih mana yang penting dan yang akan dipelajari, dan membuat kesimpulan sehingga mudah difahami oleh diri dendiri maupun orang lain.(Sugiyono, 2016, hlm. 244) 
Pemanfaatan Aplikasi Edmodo dalam Evaluasi Pembelajaran Bahasa Arab di Masa Pandemi COVID19

\section{PEMBAHASAN}

\section{Cara Membuat akun Guru di aplikasi Edmodo}

Untuk melakukan evaluasi pada aplikasi edmodo guru harus memiliki akun edmodo terlebih dahulu dengan cara mendaftar di situs edmodo https://www.edmodo.com. Cara mendaftarnya adalah sebagai berikut :

Membuka browser kemudian ketik edmodo maka akan muncul tampilan seperti berikut :

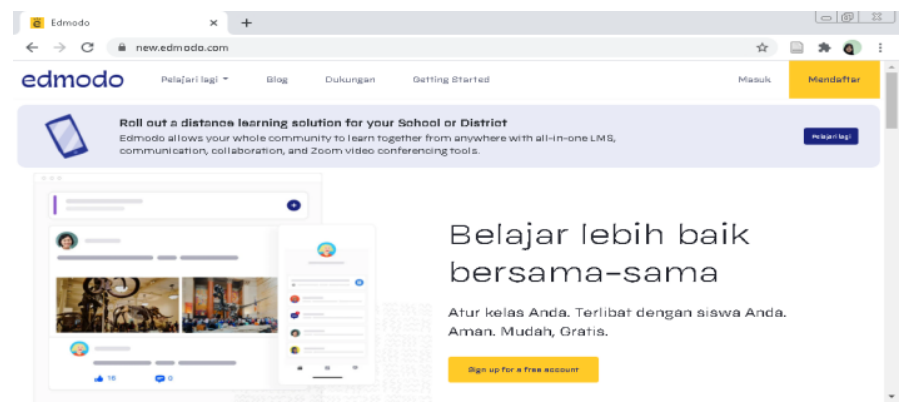

Klik Mendaftar/ Sign up

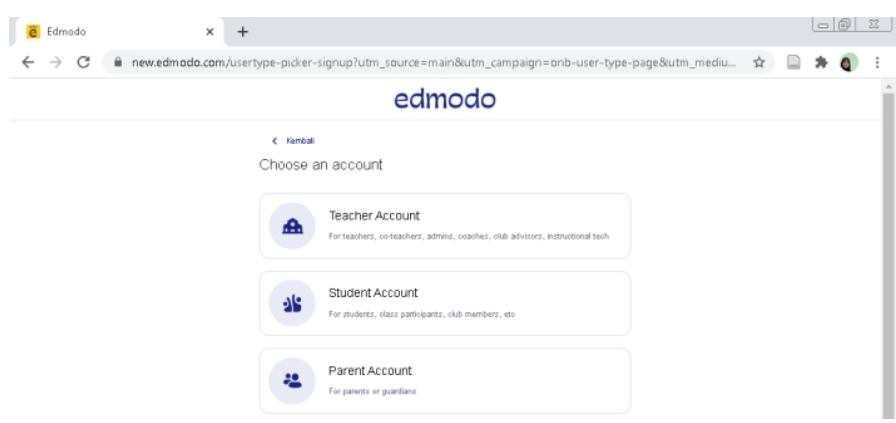

Pilih Teacher Account

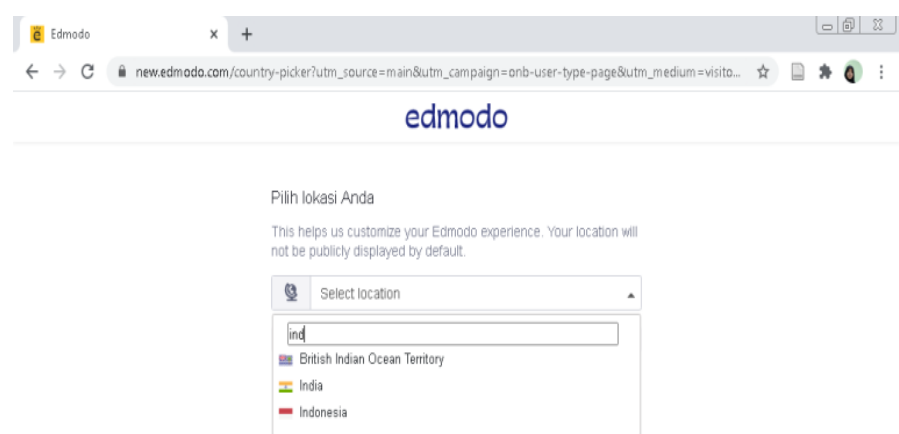

Pilih lokasi Negara Indonesia, klik next 


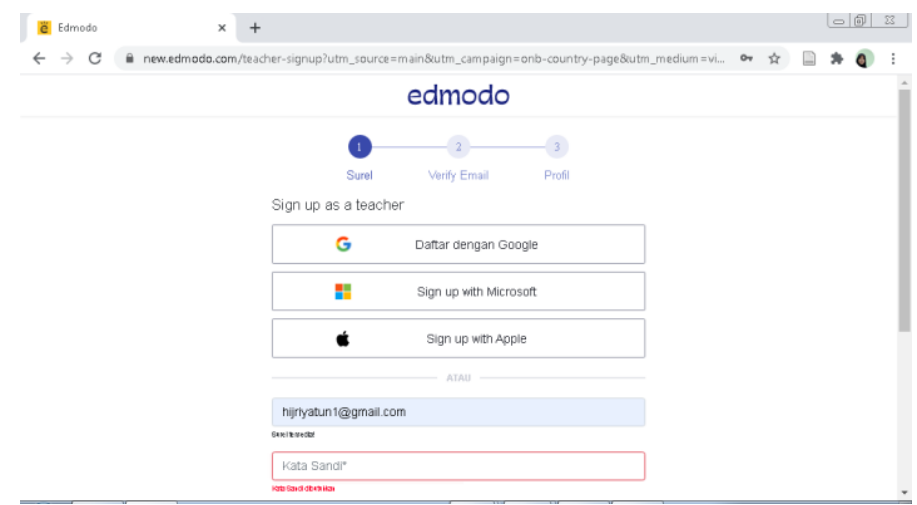

Masukkan email dan buat password untuk log in ke akun edmodo, password yang diminta minimal menggunakan 8 karakter dengan kombinasi huruf dan angka.

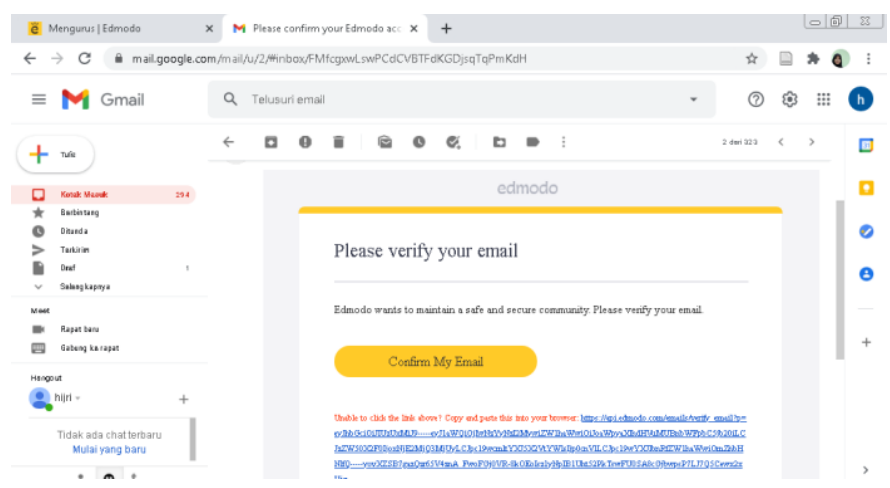

Selanjutnya kita akan diminta untuk mengkonfirmasi email, masuk terlebih dahulu ke akun email lihat dikotak masuk dan klik pemberitahuan dari edmodo, klik confirm My Email kemudian klik next, klik sign up for free, maka akan muncul tampilan dibawah ini :

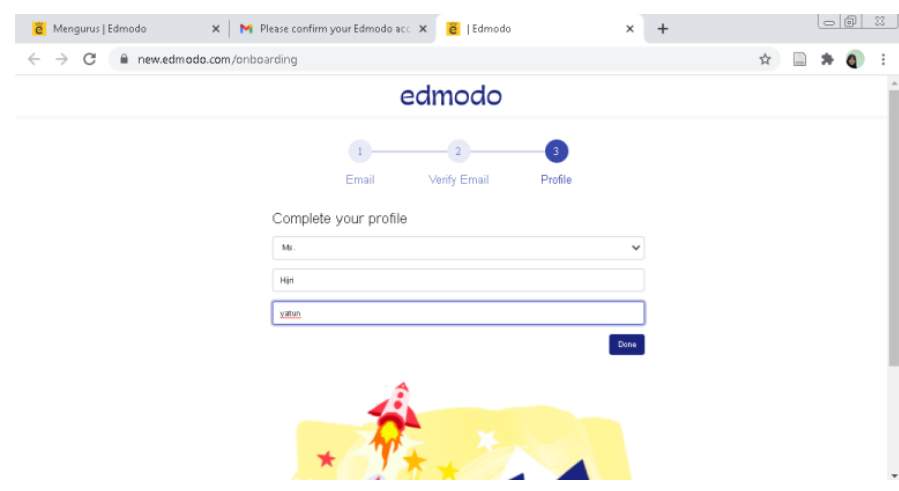

Kemudian isi data, title, nama depan, nama belakang dan klik Done 


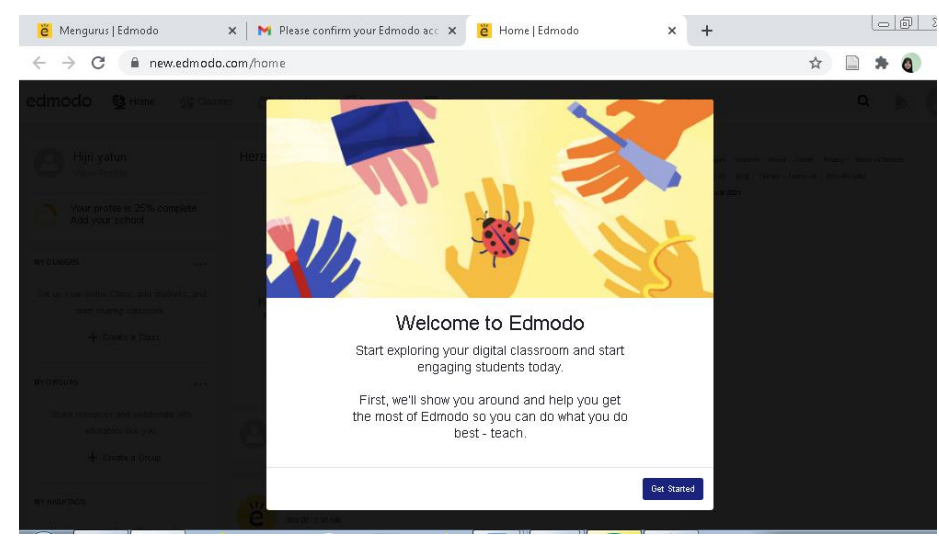

Proses pendaftaran akun edmodo sebagai guru telah selesai, kelas edmodo siap untuk digunakan, langkah selanjutnya adalah membuat kelas didalam akun edmodo, guru bisa memasukan pembagian kelas di sekolah nyata kedalam akun edmodo yang telah dibuat oleh guru.

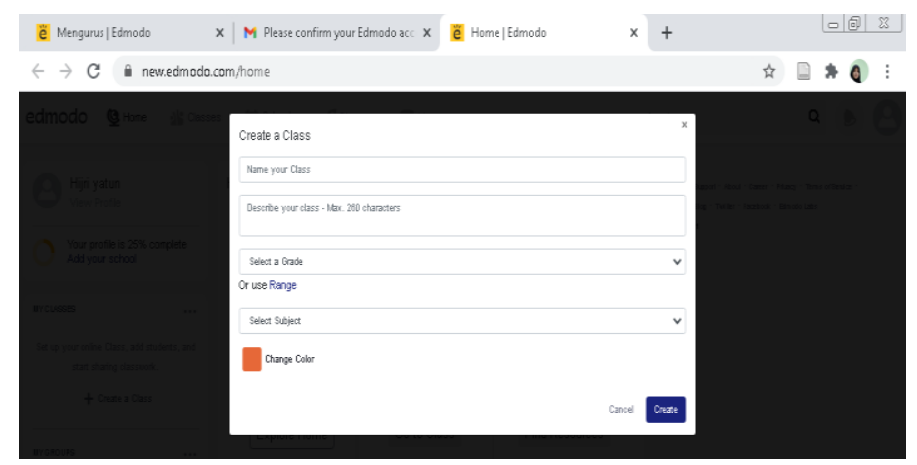

Masukan nama kelas, deskripsi kelas, tingkatan siswa dan subjek kemudian klik create

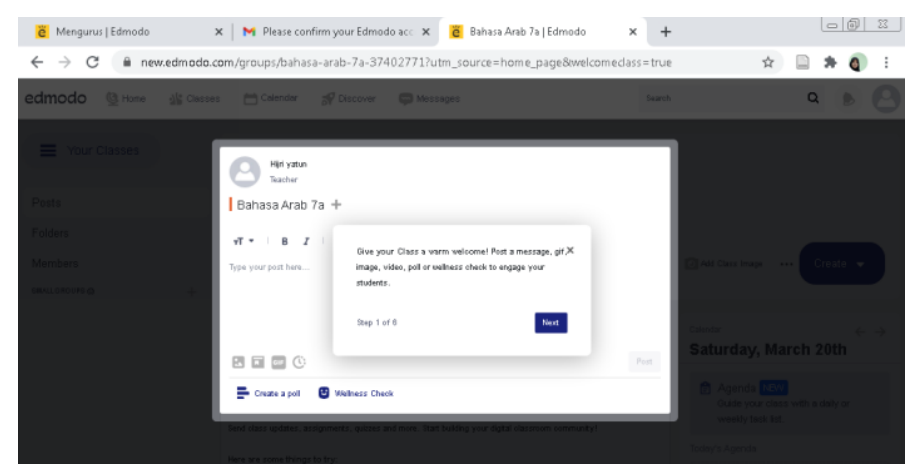

Kelas bahasa Arab siap digunakan, langkah selanjutnya adalah memasukan siswa kedalam kelas yang telah dibuat. 


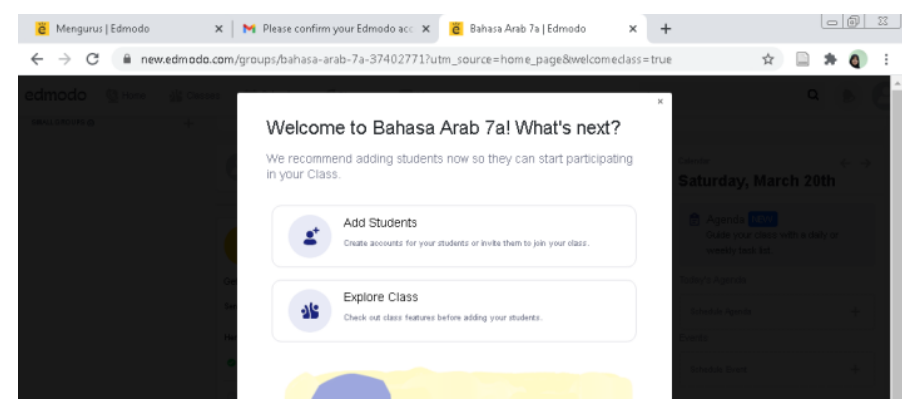

Klik Add student

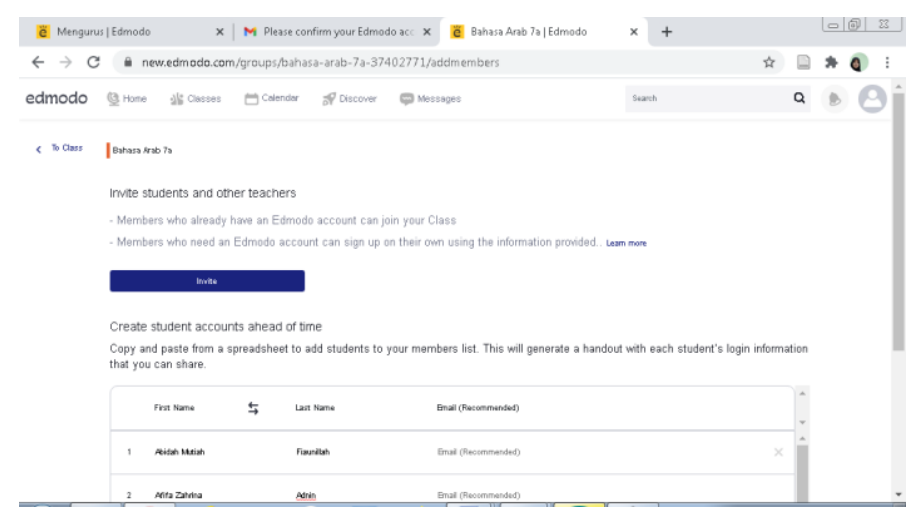

Kemudian isi data siswa yang akan dimasukkan kedalam kelas, bila seluruh siswa sudah dimasukkan klik Create student Account

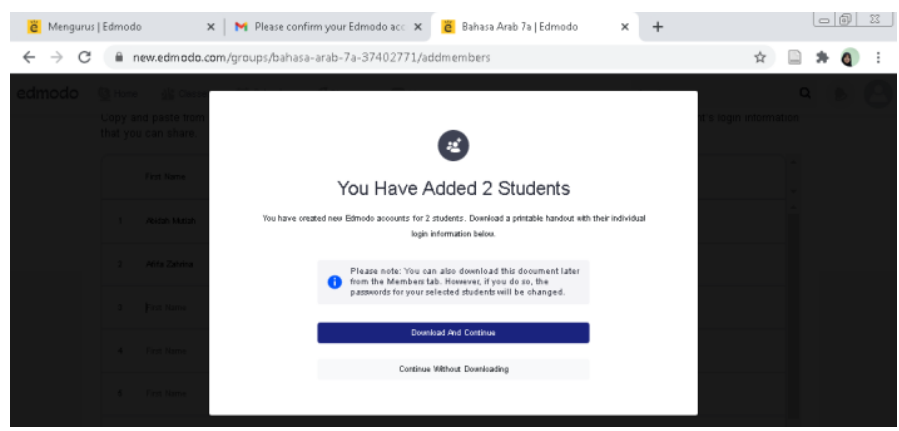

Klik download and continue, maka akan muncul nama akun siswa sekaligus password yang akan dipakai siswa untuk masuk ke kelas yang telah di buat oleh guru.

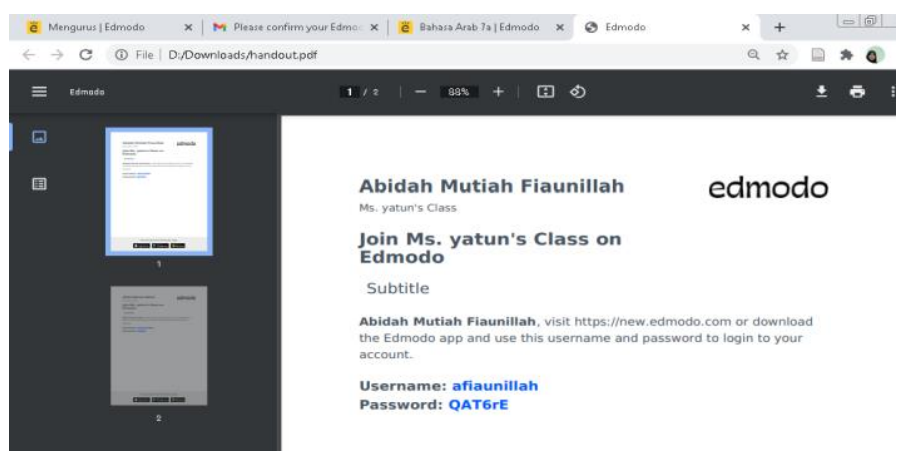


Pemanfaatan Aplikasi Edmodo dalam Evaluasi Pembelajaran Bahasa Arab di Masa Pandemi COVID19

Berikut adalah panduan untuk siswa ketika akan masuk dikelas edmodo:

Cara Log in kelas edmodo Bahasa Arab :

1. Klik chrome/Browser

2. Ketik edmodo

3. Pilih Tulisan edmodo

4. Ketik log in/masuk

5. Masukan username dan password yang diberikan oleh Guru. (Harap diperhatikan penulisan username dan password harus sama persis dengan yang diberikan oleh guru. Besar kecilnya huruf harus diketik dengan benar)

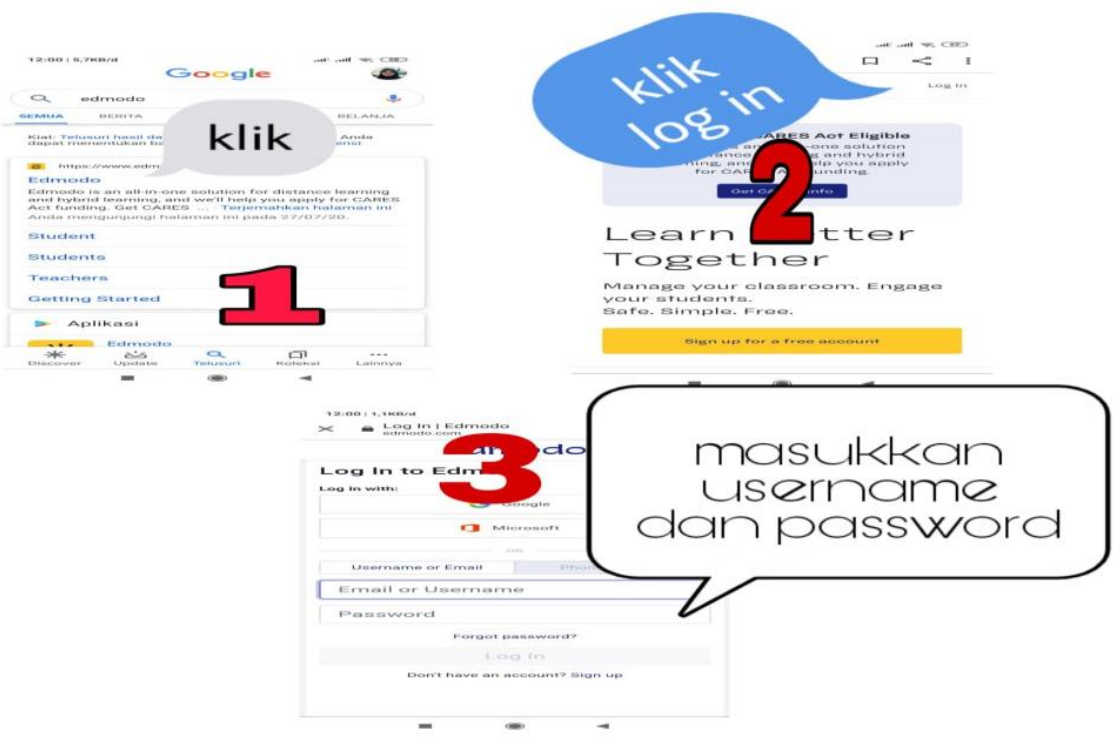

\section{Cara memasukkan soal evaluasi di akun edmodo}

Guru login kedalam akun Edmodo

Pilih kelas yang akan diberi evaluasi

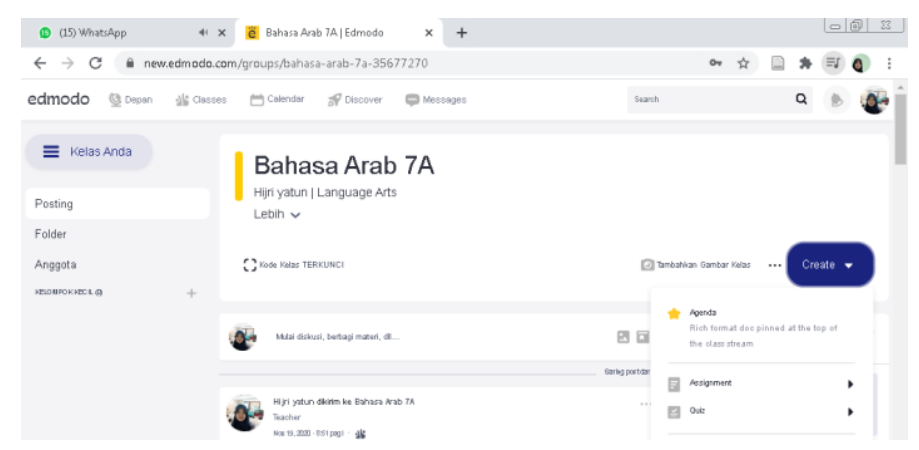

Pilih Create

Pilih Asigment bila tugas meminta siswa untuk mengirim file, atau upload gambar. 
Pilih Quiz untuk evaluasi yang berbentuk benar/salah, pilihan ganda, Jawaban singkat, Isi bagian yang rumpang/kosong, menjodohkan, beberapa jawaban.

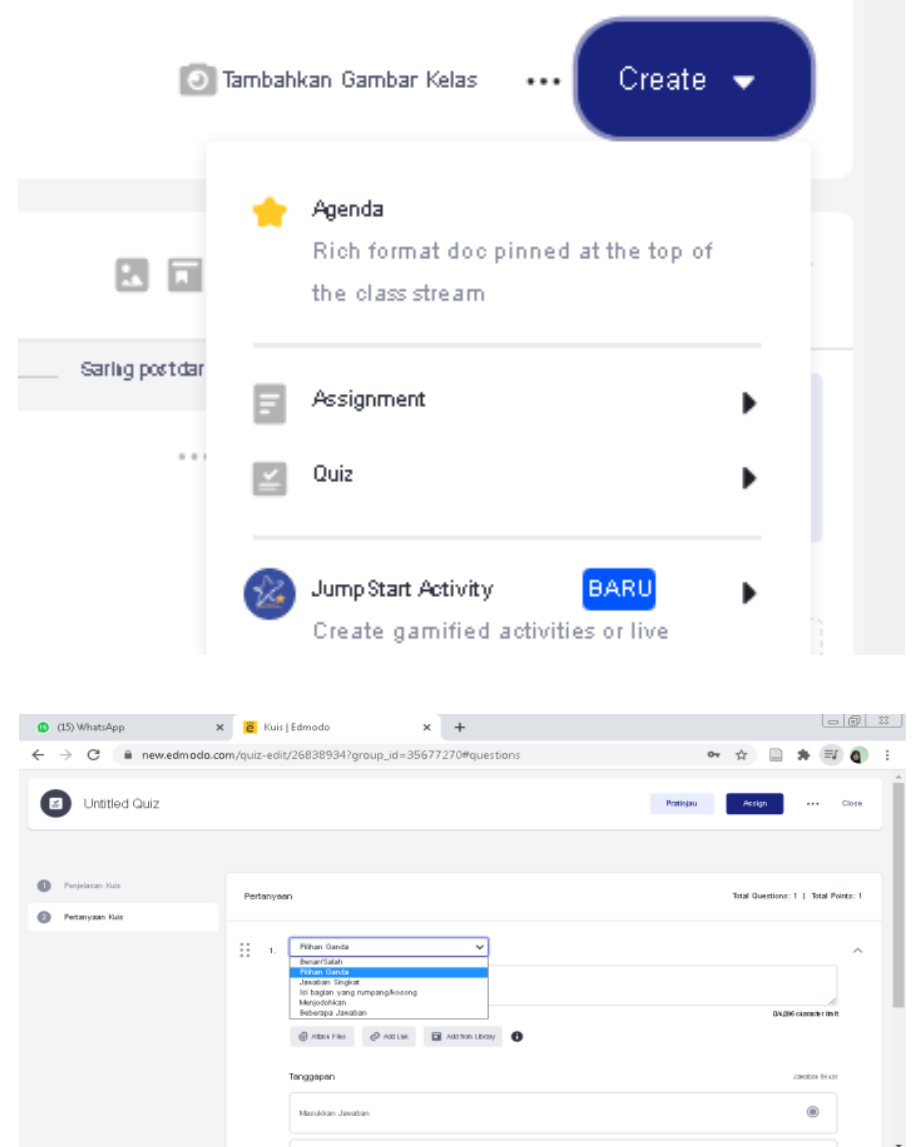

Kelebihan evaluasi menggunakan aplikasi edmodo adalah :

1) guru bisa melihat berapa siswa yang telah mengerjakan tugas

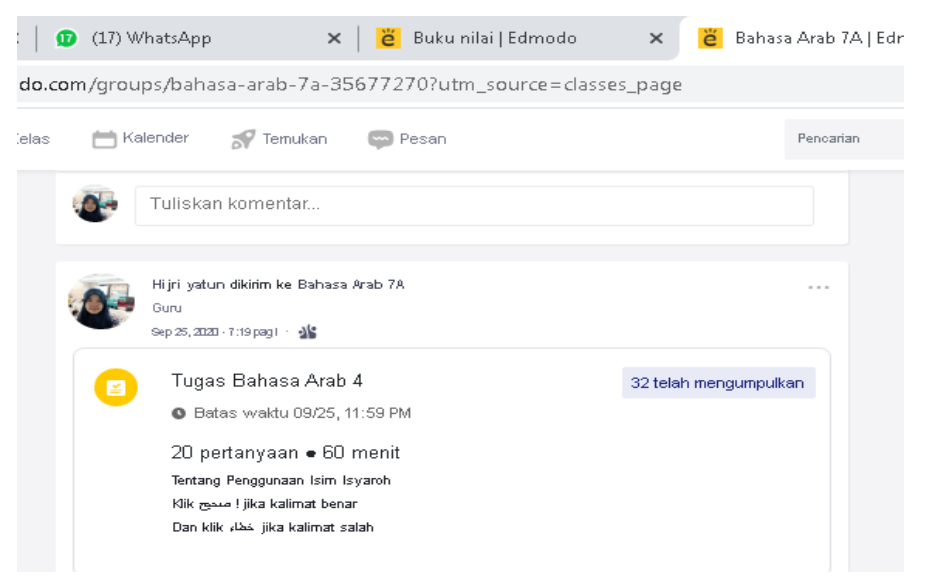


Pemanfaatan Aplikasi Edmodo dalam Evaluasi Pembelajaran Bahasa Arab di Masa Pandemi COVID19

2) guru bisa melihat prosentase pengerjaan tugas siswa

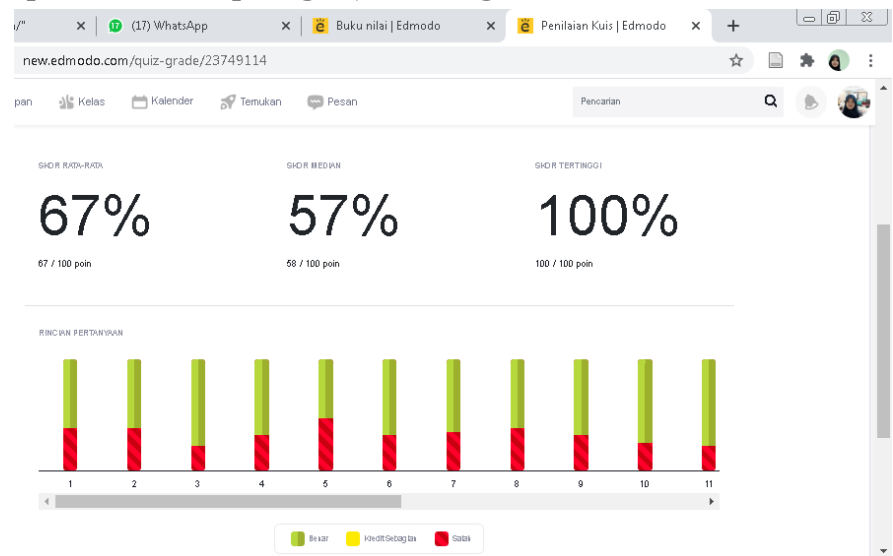

3) guru bisa mengetahui keaktifan siswa dari tanggal dan waktu pengerjaan tugas yang diberikan kepada siswa sekaligus skor yang didapat oleh siswa.

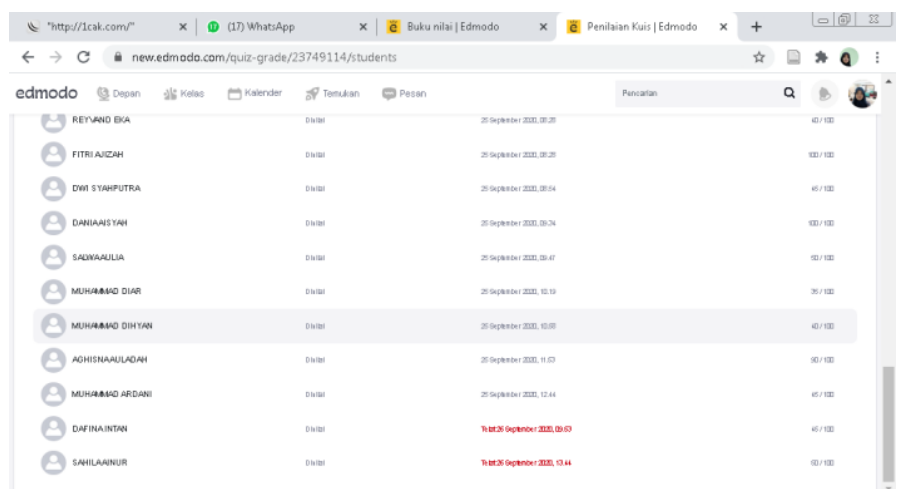

4) guru bisa memantau perkembangan kemampuan peserta didik dari beberapa tugas yang diberikan oleh guru.

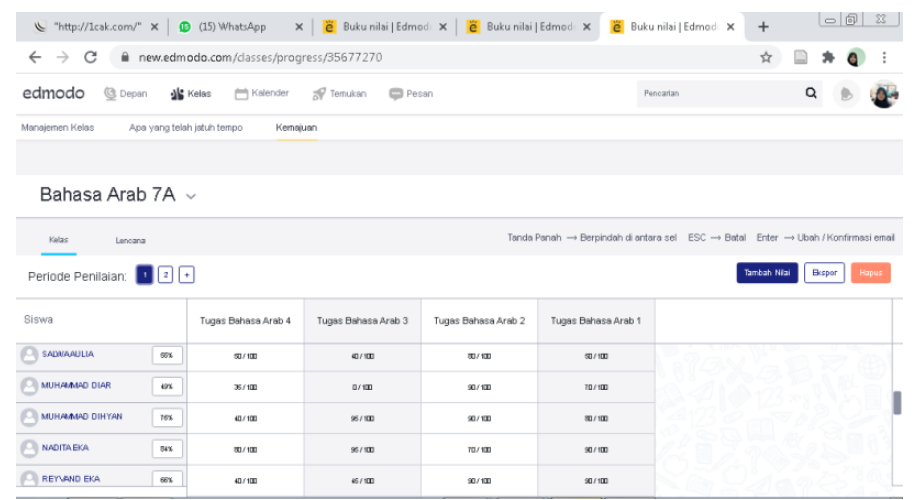

5) guru bisa melihat detail perkembangan pengerjaan tugas dari setiap individu siswa.

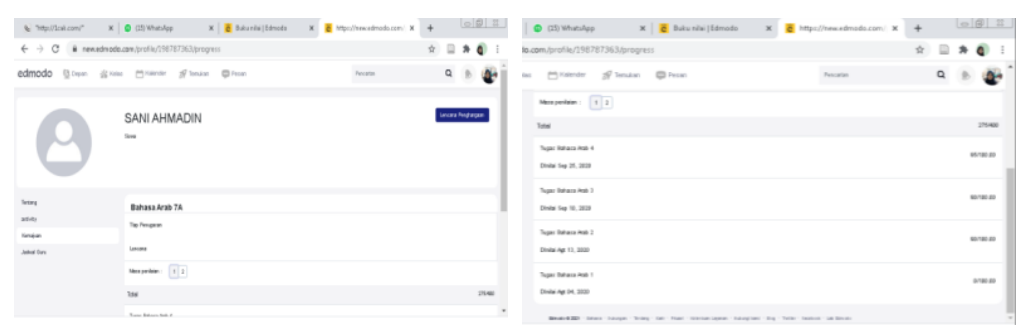


6) fitur pesan bisa digunakan oleh guru untuk mengingatkan siswa mengerjakan tugas yang belum dikerjakan

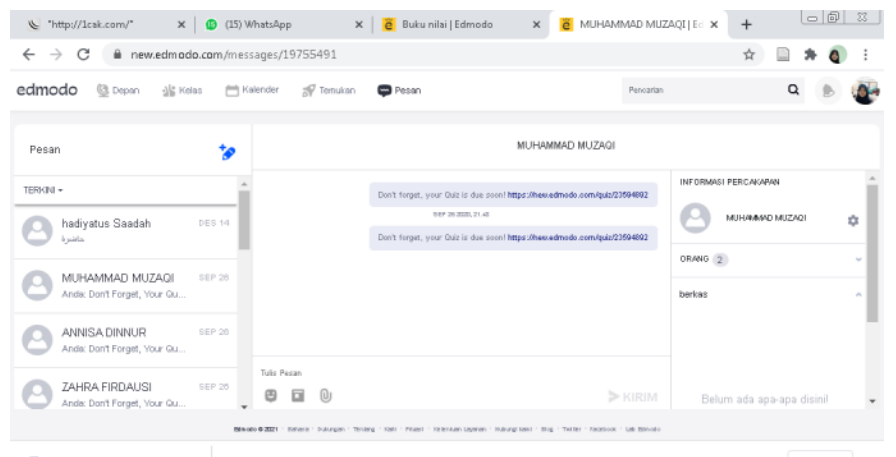

\section{Kekurangan dari Evaluasi menggunakan aplikasi edmodo}

1) Belum ada fitur video conference sehingga penilaian yang berbentuk maharah kalam belum bisa dilakukan.

2) Siswa hanya bisa mengerjakan evaluasi 1 kali, bila nilai rendah siswa tidak bisa memperbaiki nilainya.

3) Bila terjadi error pada jaringan internet siswa, siswa yang sudah membuka evaluasi pada saat itu akan kesulitan untuk mengirim tugas dan nilai akan muncul 0 (Nol)

4) Pada soal menjodohkan hanya bisa dijawab mengunakan pc, sedangkan siswa yang menggunakan smartphone tidak bisa mengerjakan soal tersebut.

Setelah peneliti melakukan pengumpulan data, observasi dan melakukan wawancara di lapangan hasilnya adalah evaluasi menggunakan aplikasi Edmodo sangat membantu guru untuk melihat perkembangan capaian peserta didik, nilai peserta didik dapat terangkum secara sistematis pada buku nilai di aplikasi edmodo, presentase kesediaan peserta didik dalam mengerjakan tugas mencapai 90\% dibandingkan ketika mengerjakan tugas yang di sampaikan melalui grup WA kelas dan mengirim secara manual kepada Guru mata pelajaran, guru juga bisa menilai tingkat kedisiplinan siswa dalam proses penyelesaian tugas yang diberikan karena tanggal dan waktu tercatat secara detail di aplikasi Edmodo, analisis butir soal juga sudah terangkum secara detail sehingga guru mata pelajaran bisa melihat soal mana yang sudah dikuasai peserta didik dan soal soal yang yang sulit hal ini 
Pemanfaatan Aplikasi Edmodo dalam Evaluasi Pembelajaran Bahasa Arab di Masa Pandemi COVID19

memudahkan guru mata pelajaran untuk melakukan tindak lanjut dalam memberikan materi pelajaran selanjutnya.

\section{KESIMPULAN}

Pada masa pandemic covid 19 seperti saat ini, pembelajaran dilakukan secara daring, evaluasi pembelajaranpun dilakukan secara daring, Untuk memudahkan evaluasi, guru bisa menggunakan berbagai macam aplikasi evaluasi online yang sudah ada salah satunya adalah aplikasi Edmodo, dengan menggunakan aplikasi Edmodo guru bisa memantau perkembangan pembelajaran yang telah dicapai oleh siswa. Hal ini bisa menjadi acuan bagi guru untuk melihat kekurangan pada proses pembelajaran dan memperbaiki cara penyampaian materi pembelajaran.

\section{DAFTAR PUSTAKA}

Ainin, M., Tohir, M., \& Asrori, I. (2006). Evaluasi Pembelajaran Bahasa Arab. Misykat.

Basori. (2013). Pemanfaatan Social Learning Network "Edmodo" dalam Membantu Perkuliahan Teori Bodi Otomotif di Prodi PTM JPTK FKIP UNS. JIPTEK: Jurnal Ilmiah Pendidikan Teknik dan Kejuruan, Vol. 06(02).

Damanik, S., Zuhdi, M., \& Herlina, H. (2020). Model Evaluasi Pembelajaran Aud Berbasis Daring Di Ra Nurun Namirah Medan Marelan studi Kasus Selama Masa Pandemi Covid-19). Al-Fatih: Jurnal Pendidikan dan Keislaman, Vol. 03(01).

Fauzi, Moh. F., \& Anindiati, I. (2020). E-Learning Pembelajaran Bahasa Arab. UMM Press.

Fitrah, Moh., \& Ruslan. (2021). Eksplorasi Sistem Pelaksanaan Evaluasi Pembelajaran di Sekolah pada Masa Pandemi Covid-19 di Bima. JURNAL BASICEDU : Research \& Learning in Elementary Education, Vol. 05(01). https://doi.org/10.31004/basicedu.v5i1.639

Fitrah, Muh, \& Luthfiyah. (2018). Metodologi penelitian: Penelitian kualitatif, tindakan kelas \& studi kasus. Jejak.

Matsna, M., \& Mahyudin, E. (2012). Pengembangan Evaluasi dan Tes Bahasa Arab. Al Kitabah.

Media, K. C. (2021, Maret 14). Update Corona Global 14 Maret 2021: Dubai Uji Coba Deteksi Covid-19 Melalui Napas Halaman all. KOMPAS.com. https://www.kompas.com/tren/read/2021/03/14/083106565/update-coronaglobal-14-maret-2021-dubai-uji-coba-deteksi-covid-19-melalui

Mendikbud Terbitkan SE tentang Pelaksanaan Pendidikan dalam Masa Darurat Covid-19. (2020, Maret 24). Kementerian Pendidikan Dan Kebudayaan. https://www.kemdikbud.go.id/main/blog/2020/03/mendikbud-terbitkan-setentang-pelaksanaan-pendidikan-dalam-masa-darurat-covid19

Sugiyono. (2016). Metode Penelitian Kuantitatif, Kualitatif dan R\&D. Alfabeta.

Sukmadinata, N. S. (2012). Metode Penelitian Pendidikan. Remaja Rosdakarya.

Suriadhi, G., Kade Tastra, I. D., \& Suwatra, Ign. W. (2014). Pengembangan E-Learning Berbasis Edmodo Pada Mata Pelajaran IPA Kelas VIII Di SMP Negeri 2 Singaraja. 
Edutech : Jurnal Universitas Pendidikan Ganesha Jurusan Teknologi Pendidikan, Vol. 02(01).

Tolinggi, S. O., \& Ramadani S, F. (2020). Optimalisasi Pembelajaran Bahasa Arab Di Era Adaptasi Kebiasaan Baru (AKB). Taqdir, 6(2), 95-116. https://doi.org/10.19109/taqdir.v6i2.6428

UPDATE Corona Indonesia 12 Maret 2021: Total 1.410.134 Positif, 1.231.454 Sembuh, 38.229 Meninggal. (t.t.). Tribunnews.com. Diambil 14 Maret 2021, dari https://www.tribunnews.com/corona/2021/03/12/update-corona-indonesia-12maret-2021-total-1410134-positif-1231454-sembuh-38229-meninggal

Wahyuningsih, D., \& Makmur, R. (2017). E-Learning Teori dan Aplikasi Proses Pembelajaran Berbasis Aplikasi, Web, Cloud Computing dalam Dunia Teknologi Informasi. Informatika. 